\title{
Australian Journal of

\section{Productive and morphogenetic characteristics of sunflower irrigated with domestic treated wastewater on northeast semiarid area}

\author{
Fabrícia Gratyelli Bezerra Costa ${ }^{1}$, Rafael Oliveira Batista ${ }^{1 *}$, Joaquim Odilon Pereira ${ }^{1}$, Miguel Ferreira \\ Neto $^{2}$, Sandra Maria Campos Alves ${ }^{3}$, Welson Lima Simões ${ }^{4}$, Luiz Di Souza ${ }^{5}$, Roberto Vieira Podeus ${ }^{1}$ \\ ${ }^{1}$ Universidade Federal Rural do Semi-Árido, Departamento de Engenharia e Ciências Ambientais, 59625-900, \\ Mossoró - RN, Brazil \\ ${ }^{2}$ Universidade Federal Rural do Semi-Árido, Departamento de Ciências Agronômicas e Florestais, 59625-900, \\ Mossoró - RN, Brazil \\ ${ }^{3}$ Instituto Federal de Educação, Ciência e Tecnologia do Rio Grande do Norte, 59190-000, Canguaretama-RN, Brazil \\ ${ }^{4}$ Empresa Brasileira de Pesquisa Agropecuária, Unidade Semiárido, 56302-970, Petrolina-PE, Brazil \\ ${ }^{5}$ Universidade do Estado do Rio Grande do Norte, Faculdade de Ciências Exatas e Naturais, 59600-000, Mossoró-RN, \\ Brazil
}

*Corresponding author: rafaelbatista@ufersa.edu.br

\begin{abstract}
The present study aimed to evaluate the agronomic performance of the sunflower crop irrigated with treated domestic wastewater and normal water (well-water) in a inceptisol of Apodi, State of Rio Grande do Norte, Brazil. The experiment was conducted in a randomized block experimental design, consisting of five treatments and five replications, using the $\mathrm{H}-251$ sunflower cultivar from Embrapa. The treatments consisted of the application of five proportions of wastewater/well-water (T1 - 100\% wastewater; T2 $75 \%$ wastewater and $25 \%$ well water, T3 - 50\% wastewater and $50 \%$ well-water, T4 - $25 \%$ wastewater and $75 \%$ well-water and T5 $100 \%$ well-water plus chemical fertilizer, control). The variables such as plant height, leaf number, diameter of stem and the head, yield, oil production, thousand-grain weight and head weight were evaluated. The combined use of wastewater and well-water is an alternative for the substitution of mineral fertilization with minimal damage to the productive potential and development of the sunflower crop. In general, the T4 treatment was the most adequate to improve agronomic performance of the sunflower.
\end{abstract}

Keywords: Helianthus annuus L, liquid waste, water reuse, agronomic performance.

Abbreviations: SD_Stem diameter; HD_head diameter; PH_plant height; NF_number of leaves; PO_production of oil; WTG_weight of a thousand grains; HW_head weight; PR_sunflower productivity; DAT_day cycle after the sunflower transplanting.

Introduction

According to Leoneti et al. (2011), investments in sewerage system are efficient and economically feasible alternatives, since treated domestic wastewater can be used in the irrigation, toilet flushing, car washing and floor cleaning activities, contributing to the reduction of the use of drinking water for these purposes. At the same time, this can generate positive impact on human health and the environment, preventing pollution and ensuring the quality of water for consumption and controlling the proliferation of disease-causing vectors.

The use of wastewater in agriculture provides advantages such as the reuse of water and the reduced use of mineral fertilizers due to application of organic matter and nutrients through irrigation systems and decrease in use of good quality water. This will help reducing the potential pollution to the environment, and disadvantages such as the occurrence of negative environmental impacts to the soilplant system, contamination of soil, surface water and groundwater and toxicity to plants (Rodrigues et al., 2011).
Sunflower (Helianthus annuus L.) is an oleaginous plant with several uses such as: edible, biodiesel, ornamentation, animal feed and honey production (Fabio et al., 2015). It is a herbaceous, dicotyledonous plant, belong to the Compositae family, which has a deep root system, reaching $2 \mathrm{~m}$ deep, usually with numerous secondary roots. It also presents good resistance to heat and drought; thus, becoming an important agricultural alternative for the Brazilian semiarid region (Soares et al., 2015).

According to the Agrianual (2014), sunflower productivity in the Northeastern region is low $\left(400 \mathrm{~kg} \mathrm{ha}^{-1}\right)$, which corresponds to only $25.42 \%$ of the national average productivity (1574 $\mathrm{kg} \mathrm{ha}^{-1}$ ). This is usually attributed to the uneven rainfall distribution (Santos et al., 2009) and the low availability of macronutrients (nitrogen, phosphorus and potassium) in the soils of some Brazilian semiarid regions (Menezes and Silva, 2008; Feitosa et al. 2013).

In Brazil, there is interest in sunflower production, as this crop is among the top five oilseeds producing edible 
vegetable oil, behind only soybean, cotton, canola (rapeseed) and peanut (Moraes et al., 2012; Agrianual, 2014) and among the plant species of greatest potential for the production of renewable energy (biodiesel).

The agricultural use of treated domestic wastewater represents an alternative to the semiarid zone, minimizing problems of water scarcity and inadequacy of sanitary sewage systems due to the supply of water, nutrients and organic matter to the soil. This may lead to improvement of the physical and chemical quality of the soil (Santos et al., 2006, Souza et al., 2010) and reduction in production costs (Moraes et al., 2012).

Some studies confirm the benefits of using wastewater in sunflower, among them the use of effluents from the meat industry (Moraes et al., 2012), treated domestic wastewater (Nobre et al., 2010; Andrade et al., 2012), and sewage sludge (Lobo and Grassi Filho, 2007; Silva et al., 2010) and water produced from petroleum (Weber et al., 2017), which may partially or fully meet the nutritional needs of sunflower crop and allow development and production levels equal to or greater than those achieved in the traditional production system. In this sense, Rawashdeh (2017), verified the maximization of seed yield and oil production in sunflower plants irrigated with treated domestic wastewater. Oliveira et al. (2017) studied the effects of five dilutions of treated domestic wastewater in supply water on the development and production of sunflower. They reported that irrigation with wastewater caused no significant change on external diameter of flower bud, beginning of flowering and the full opening of head and irrigation, while the wastewater favored the development of sunflower, especially in the dilution of $100 \%$ domestic wastewater.

The treatment of wastewater for agricultural use minimized soil physicochemical alterations, losses in the agronomic performance of crop and microbiological contamination of agricultural product (Carvalho et al., 2013; Weber et al., 2017). According to Carvalho et al. (2013), treated domestic wastewater at the secondary level allowed the production of sunflower biomass within acceptable sanitary standards for food and feed. Weber et al. (2017) produced sunflower irrigated with well-water and water produced from the treated oil by filtration and reverse osmosis, evidenced that the water produced from filtered petroleum only modified the concentration of exchangeable salts in the soil, affecting the vegetative growth and the accumulation of nutrients in the roots and aerial parts of plants. On the other hand, the water produced from petroleum treated by reverse osmosis did not cause a change in the agronomic performance of the sunflower compared to irrigation with well-water.

The present study aimed to analyze the effects of treated domestic wastewater and well-water on the alteration of productive and morphologic characteristics of sunflower grown in the Brazilian semiarid region.

\section{Results and Discussion}

\section{Contribution of nutrients to sunflower by the proportions of} treated domestic wastewater and well-water

The mean nutrient concentrations in the treated domestic wastewater and well-water are shown in Table 2 .
Furthermore, the volume of nutrients applied by irrigation during the experimental period and nutrient inputs were estimated (Table 3).

According to the nutritional requirements of sunflower and the initial chemical analysis of the soil (Table 1), the irrigation with wastewater is capable to satisfy almost the complete requirement of plant to $\mathrm{N}$ and $\mathrm{K}_{2} \mathrm{O}$ and partially the requirements of $\mathrm{P}_{2} \mathrm{O}_{5}$ and $\mathrm{Ca}$.

The sodium was the nutrient that was highly added to the soil, ranging from 39 to $600 \mathrm{~kg} \mathrm{ha}^{-1}$. In addition to providing high amounts of sodium, the treated domestic wastewater also contributed large amounts of nitrogen to the soil, with a maximum value of $201 \mathrm{~kg} \mathrm{ha}^{-1}$.

This contribution of sodium is high and might be a limiting factor for the use of domestic wastewater in agriculture, when compared to soils that received only irrigation (surface water) with low sodium concentration and electrical conductivity lower than $0.70 \mathrm{dS} \mathrm{m}^{-1}$ (Medeiros et al., 2005).

\section{Effect of proportions (ratio) of treated domestic wastewater and well-water on the morphologic characteristics of sunflower}

The effect of proportions (ratio) of treated domestic wastewater/well-water on the morphologic characteristics of the sunflower at 66 days after transplanting is shown in Table 4.

The treated domestic wastewater and well-water ratios had a significant effect on stem diameter (SD) and head diameter (HD) of sunflower. The data showed significant difference between the treatments for SD and HD, by the Tukey's test. However, there was no significant effect of the proportions of treated domestic wastewater and well-water on plant height (PH) and number of leaves (NF).

Our results differed in part from those obtained by Andrade et al. (2012), who found significant differences in water types (treated domestic wastewater and well-water) on variables such as $\mathrm{PH}, \mathrm{NF}, \mathrm{SD}$ and $\mathrm{HD}$ of ornamental sunflower under experimental.

Analyzing the orthogonal contrasts, we verified that contrasts for SD and HD were significant (C1). The treatments with treated domestic wastewater showed an increase value of SD of $20.47 \%$ (T1), $7.48 \%$ (T2), 21.39\% (T3) and $21.39 \%(\mathrm{~T} 4)$, and improvement for the HD value of $11.56 \%$ (T1), 7.73 (T2), $21.55 \%$ (T3) and $22.67 \%$ (T4) compared to $\mathrm{T} 1$. The $\mathrm{C} 2$ and $\mathrm{C} 3$ contrasts were significant only for the $\mathrm{HD}$ variable, while the $\mathrm{C} 4$ contrast was significant only for the SD variable.

The nutrients provided by the treated domestic wastewater (T1 to T4 treatments) (Table 3), provide similar performance to the $\mathrm{PH}$ and NF variables compared to T5. These results differ from those found by Andrade et al. (2012), where the values of PH and NF were significantly increased in plants irrigated with treated domestic wastewater compared to the well-water.

However, for the SD and HD variables, the lowest performance was observed in $\mathrm{T} 2$, probably due to the higher amount of potassium provided by the treated domestic wastewater and well-water ratio (Table 3 ), which may have caused nutritional imbalance in the soil. 
Table 1. Chemical and physical characteristics of the soil used in the experiment, before applying the treated domestic wastewater and well water ratios.

\begin{tabular}{|c|c|c|c|c|c|c|c|c|c|c|c|c|c|c|c|}
\hline $\begin{array}{l}\text { Depth of soil } \\
\text { (m) }\end{array}$ & $\begin{array}{l}\mathrm{pH} \\
\mathrm{H}_{2} \mathrm{O}\end{array}$ & $\begin{array}{l}\mathrm{MO} \\
\mathrm{g} \mathrm{kg}^{-1}\end{array}$ & $\begin{array}{l}\mathrm{P} \\
\ldots \ldots\end{array}$ & $\mathrm{K}^{+}$ & $\begin{array}{l}\mathrm{Na}^{+} \\
\ldots . \mathrm{m}\end{array}$ & $\begin{array}{l}N \\
m^{-3} \ldots\end{array}$ & B & $\mathrm{Cu}$ & $\mathrm{Zn}$ & $\begin{array}{l}\mathrm{Ca}^{2+} \\
\ldots \ldots \ldots\end{array}$ & $\begin{array}{l}\mathrm{Mg}^{2+} \\
\ldots \ldots . . \mathrm{cm}\end{array}$ & $\begin{array}{l}\mathrm{Al}^{2+} \\
\mathrm{dm}^{-3}\end{array}$ & SB & $\begin{array}{l}\text { CTC } \\
\ldots\end{array}$ & $\begin{array}{l}\mathrm{m} \\
. . \% .\end{array}$ \\
\hline $0-0.20$ & 6.7 & 1.8 & 7.7 & 138 & 125 & 0.25 & 0.3 & 0.7 & 3.1 & 2.1 & 0.6 & 0.0 & 3.05 & 4.04 & 0 \\
\hline $0.20-0.40$ & 7.2 & 1.2 & 1.4 & 106 & 120 & 0.20 & 0.2 & 0.9 & 0.5 & 1.8 & 0.6 & 0.0 & 2.67 & 3.17 & 0 \\
\hline $0.40-0.60$ & 6.5 & 1.1 & 0.7 & 134 & 118 & 0.18 & 0.3 & 0.5 & 0.4 & 3.5 & 1.3 & 0.0 & 5.14 & 5.14 & 0 \\
\hline Depth of soil & \multirow{2}{*}{\multicolumn{6}{|c|}{$\begin{array}{l}\text { Soil bulk density } \\
\mathrm{g} \mathrm{cm}^{-3}\end{array}$}} & \multirow{2}{*}{\multicolumn{2}{|c|}{$\begin{array}{l}\text { Sand } \\
\ldots \ldots \ldots . . .\end{array}$}} & \multirow{2}{*}{\multicolumn{2}{|c|}{$\begin{array}{l}\text { Silt } \\
\mathrm{kg} \mathrm{kg}^{-1} \text {. }\end{array}$}} & Clay & & \multicolumn{3}{|c|}{ Water content (\%) } \\
\hline (m) & & & & & & & & & & & $\ldots \ldots \ldots$ & & 0.011 & & 1.5MPa \\
\hline $0-0.20$ & 1.80 & & & & & & 0.83 & & 0.07 & & 0.10 & & 28.6 & & 6.2 \\
\hline $0.20-0.40$ & 1.69 & & & & & & 0.55 & & 0.07 & & 0.38 & & 18.2 & & 12.2 \\
\hline $0.40-0.60$ & 1.73 & & & & & & 0.47 & & 0.06 & & 0.47 & & 18.0 & & 12.7 \\
\hline
\end{tabular}

Fig 1. Schematic illustration of the experimental design used to conduct the experiments on sunflower crop, such as treated domestic well-water and well-water tanks, pumping systems, automation system, experimental plots, main and bypass pipelines and lateral lines for the application of proportions of treated domestic wastewater and water from well. Treated domestic wastewater reservoir; 2 - Well-water reservoir; 3 - Treated domestic wastewater pumping and filtration system; 4 - Well-water pumping and filtration system; 5 - Automated system for the application of proportions of treated domestic wastewater and well water; 6 - Main and derivation lines; 7 - Experimental plot irrigated by lateral lines; T1 - Sunflower crop irrigated with 100\% treated domestic wastewater; T2 - Sunflower crop irrigated with $75 \%$ treated domestic wastewater plus $25 \%$ well water; T3 - Sunflower crop irrigated with $50 \%$ treated domestic wastewater plus $50 \%$ well water; T4 - Sunflower crop irrigated with $25 \%$ treated domestic wastewater plus $75 \%$ well water; e T5 - Sunflower crop irrigated with $100 \%$ well water.

Table 2. Mean values of physical-chemical characteristics of treated domestic wastewater and well-water, from four samplings held in the period from September 22 to December 28, 2011.

\begin{tabular}{|c|c|c|c|c|c|c|c|c|}
\hline Treatments & $\mathrm{pH}$ & 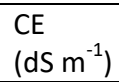 & $\begin{array}{l}\mathrm{Na}^{+} \\
\left(\mathrm{mmol}_{\mathrm{c}} \mathrm{L}^{-1}\right)\end{array}$ & $\begin{array}{l}\mathrm{Ca}^{2+} \\
\left(\mathrm{mmol}_{\mathrm{c}} \mathrm{L}^{-1}\right)\end{array}$ & $\begin{array}{l}\mathrm{Mg}^{2+} \\
\left(\mathrm{mmol}_{\mathrm{c}} \mathrm{L}^{-1}\right)\end{array}$ & $\begin{array}{l}\mathrm{N} \\
\left(\mathrm{mg} \mathrm{L}^{-1}\right)\end{array}$ & $\begin{array}{l}\mathrm{P} \\
\left(\mathrm{mg} \mathrm{L}^{-1}\right)\end{array}$ & $\begin{array}{l}\mathrm{K}^{+} \\
\left(\mathrm{mg} \mathrm{L}^{-1}\right)\end{array}$ \\
\hline $\begin{array}{l}\text { Treated } \\
\text { domestic } \\
\text { wastewater }\end{array}$ & 6.82 & 1.21 & 6.21 & 1.19 & 1.02 & 111.00 & 6.70 & 41.1 \\
\hline Well water & 6.96 & 0.09 & 0.46 & 0.17 & 0.28 & 0.00 & 0.00 & 11.50 \\
\hline
\end{tabular}

Table 3. Contribution of nutrients applied to the soil by drip watering with proportions/ratio of treated domestic wastewater and well-water.

\begin{tabular}{lllllll}
\hline \multirow{2}{*}{ Treatments } & $\begin{array}{l}\mathrm{N} \\
\mathrm{kg} \mathrm{ha}^{-1}\end{array}$ & $\begin{array}{l}\mathrm{P}_{2} \mathrm{O}_{5} \\
\mathrm{~kg} \mathrm{ha}^{-1}\end{array}$ & $\begin{array}{l}\mathrm{K}_{2} \mathrm{O} \\
\mathrm{kg} \mathrm{ha}^{-1}\end{array}$ & $\begin{array}{l}\mathrm{Ca} \\
\mathrm{kg} \mathrm{ha}^{-1}\end{array}$ & $\begin{array}{l}\mathrm{Mg} \\
\mathrm{kg} \mathrm{ha}^{-1}\end{array}$ & $\begin{array}{l}\mathrm{Na} \\
\mathrm{kg} \mathrm{ha}^{-1}\end{array}$ \\
\hline T1 & 201 & 32 & 105 & 88 & 34 & 600 \\
$\mathrm{~T} 2$ & 151 & 25 & 117 & 75 & 35 & 479 \\
$\mathrm{~T} 3$ & 100 & 16 & 77 & 50 & 23 & 320 \\
$\mathrm{~T} 4$ & 50 & 9 & 40 & 25 & 12 & 160 \\
T5 & 0 & 0 & 52 & 13 & 13 & 39 \\
\hline \multirow{3}{*}{ Mineral fertilization recommended } & $\mathrm{N}^{1}$ & $\mathrm{P}_{2} \mathrm{O}_{5}{ }^{1}$ & $\mathrm{~K}_{2} \mathrm{O}^{1}$ & $\mathrm{Ca}^{1}$ & $\mathrm{~S}^{1}$ & $\mathrm{~B}^{1}$ \\
& $\mathrm{~kg} \mathrm{ha}^{-1}$ & $\mathrm{~kg} \mathrm{ha}^{-1}$ & $\mathrm{~kg} \mathrm{ha}^{-1}$ & $\mathrm{~kg} \mathrm{ha}^{-1}$ & $\mathrm{~kg} \mathrm{ha}^{-1}$ & $\mathrm{~kg} \mathrm{ha}^{-1}$ \\
\cline { 2 - 7 } & 60 & 70 & 30 & 116 & 25 & 1 \\
\hline
\end{tabular}

Note: ${ }^{1}$ According to Ribeiro et al. (1999) for sunflower fertilization. 
Table 4. Effect of the proportions/ratios with treated domestic wastewater and well-water on the morphogenetic characteristics of sunflower, at 66 days after transplanting.

\begin{tabular}{|c|c|c|c|c|}
\hline \multirow{2}{*}{ Treatments } & \multicolumn{4}{|c|}{ Morphologic characteristics } \\
\hline & $\mathrm{PH}(\mathrm{m})$ & NF (und.) & $\mathrm{SD}^{1}(\mathrm{~cm})$ & $\mathrm{HD}^{1}(\mathrm{~cm})$ \\
\hline T1 & 1.00 & 12.40 & $1.71 \mathrm{a}$ & $6.75 b$ \\
\hline $\mathrm{T} 2$ & 1.03 & 13.00 & $1.47 a b$ & $6.47 b c$ \\
\hline T3 & 1.08 & 12.20 & $1.73 a$ & $7.61 a$ \\
\hline T4 & 1.05 & 12.40 & $1.73 a$ & $7.72 a$ \\
\hline T5 & 0.96 & 12.20 & $1.36 \mathrm{~b}$ & $5.97 c$ \\
\hline Mean & 1.03 & 12.44 & 1.60 & 6.90 \\
\hline Coefficient of variation (\%) & 9.46 & 7.03 & 9.18 & 5.32 \\
\hline Standard error & 0.04 & 0.39 & 0.06 & 0.16 \\
\hline Probability & $0.36^{\mathrm{NS}}$ & $0.60^{\mathrm{NS}}$ & $0.0023^{* *}$ & $0.00010^{* *}$ \\
\hline \multicolumn{5}{|l|}{ Probability of contrsts } \\
\hline 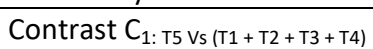 & $0.14^{\mathrm{ns}}$ & $0.46^{\text {ns }}$ & $0.0013^{* *}$ & $0.00010^{* *}$ \\
\hline Contrast $\mathrm{C}_{2:} \mathrm{T} 4 \mathrm{Vs}(\mathrm{T} 1+\mathrm{T} 2+\mathrm{T} 3)$ & $0.70^{\mathrm{ns}}$ & $0.70^{\mathrm{ns}}$ & $0.19^{\mathrm{ns}}$ & $0.00040^{* *}$ \\
\hline Contrast $\mathrm{C}_{3:}: \mathrm{T}_{3} \mathrm{Vs}_{\mathrm{s}}(\mathrm{T} 1+\mathrm{T} 2)$ & $0.23^{\mathrm{ns}}$ & $0.31^{\text {ns }}$ & $0.11^{\text {ns }}$ & $0.00010^{* *}$ \\
\hline Contrast $\mathrm{C}_{4: \mathrm{T} 2 \mathrm{Vs} \mathrm{T1}}$ & $0.56^{\mathrm{ns}}$ & $0.29^{\mathrm{ns}}$ & $0.023^{*}$ & $0.25^{\mathrm{ns}}$ \\
\hline
\end{tabular}

Note: ${ }^{1}$ Means followed by equal letters in the column do not statistically differ by the Tukey's test at $5 \%$ probability. ${ }^{* *}$ and ${ }^{*}$ Significant at 1 and $5 \%$ probability by the $\mathrm{F}$ test, respectively. ${ }^{\mathrm{ns}}$ - Not significant at $5 \%$ probability by the $\mathrm{F}$ test

Table 5. Effect of the proportions with treated domestic wastewater and well water, on the productive characteristics of sunflower, at 66 days after transplanting.

\begin{tabular}{|c|c|c|c|c|}
\hline \multirow{2}{*}{ Treatment } & \multicolumn{4}{|c|}{ Productive characteristics } \\
\hline & PR $\left(\mathrm{kg} \mathrm{ha}^{-1}\right)$ & $\mathrm{PO}^{1}(\%)$ & WTG $^{1}(\mathrm{~g})$ & $\mathrm{HW}^{2}(\mathrm{~g})$ \\
\hline T1 & 961.80 & $29.68 c$ & $69.42 b$ & $131.11 b$ \\
\hline $\mathrm{T} 2$ & 1321.40 & $37.03 b$ & $85.26 a$ & $192.24 a b$ \\
\hline T3 & 1195.60 & $36.80 \mathrm{~b}$ & $78.62 a b$ & $151.78 a b$ \\
\hline T4 & 1282.60 & $41.67 a$ & $81.53 a b$ & $213.14 a$ \\
\hline T5 & 1253.20 & 43.69a & $87.21 \mathrm{a}$ & $154.33 a b$ \\
\hline Mean & 1202.92 & 37.77 & 80.47 & 168.52 \\
\hline Coefficient of variation (\%) & 31.57 & 5.17 & 10.10 & 27.82 \\
\hline Standard error & 169.86 & 0.87 & 3.63 & 20.96 \\
\hline Probability & $0.60^{\mathrm{NS}}$ & $0.00010^{* *}$ & $0.026^{*}$ & $0.082^{*}$ \\
\hline \multicolumn{5}{|l|}{ Productive characteristics } \\
\hline Contrast $\mathrm{C}_{1:} \mathrm{T5}$ Vs $(\mathrm{T} 1+\mathrm{T} 2+\mathrm{T} 3+\mathrm{T} 4)$ & $0.73^{\mathrm{ns}}$ & $0.00010^{* *}$ & $0.050^{*}$ & $0.46^{\mathrm{ns}}$ \\
\hline Contrast $\mathrm{C}_{2:} \mathrm{T} 4 \mathrm{Vs}(\mathrm{T} 1+\mathrm{T} 2+\mathrm{T} 3)$ & $0.53^{\mathrm{ns}}$ & $0.045^{*}$ & $0.38^{\mathrm{ns}}$ & $0.041^{*}$ \\
\hline Contrast $\mathrm{C}_{3:} \mathrm{T} 3 \mathrm{Vs}(\mathrm{T} 1+\mathrm{T} 2)$ & $0.80^{\mathrm{ns}}$ & $0.0042^{* *}$ & $0.73^{\mathrm{ns}}$ & $0.70^{\mathrm{ns}}$ \\
\hline Contrast $\mathrm{C}_{4: \mathrm{T} 2 \mathrm{Vs} \mathrm{T} 1}$ & $0.15^{\mathrm{ns}}$ & $0.00010^{* *}$ & $0.0072^{* *}$ & $0.050^{*}$ \\
\hline
\end{tabular}

Note: ${ }^{1}$ Means followed by equal letters in the column do not statistically differ by the Tukey's test at $5 \%$ probability, ${ }^{2}$ Means followed by equal letters in the column do not statistically differ by the Tukey test at $10 \%$ probability. ${ }^{* *}$ and ${ }^{*}$ Significant at 1 and $5 \%$ probability by the F-test, respectively. ${ }^{\text {ns }}-$ Not significant at $5 \%$ probability by the F test.

Lima et al. (1981) noted that the potassium influence was relatively low. This influence was verified on the mass of the dry matter of the stem and dry matter of the total aerial part of the plants, only in the presence of the highest dose of phosphorus.

In the work developed by Freitas et al. (2012), the highest averages of NF per plant obtained from the treated domestic wastewater differed statistically from well-water treatment.

Santos Junior et al. (2011) evidenced a significant effect of the water types (treated domestic wastewater and wellwater) on the NF values of sunflower plants, while the variables SD and HD did not change significantly when irrigated with treated domestic wastewater and well-water.

Effect of proportion/ratio of treated domestic wastewater and well water on the productive characteristics of sunflower

Table 5 shows the results of the treated domestic wastewater and well-water proportions/ratio on the productive characteristics of the sunflower, at 66 days after transplanting.

It is worth mentioning that there was significant effect of the treatments on the production of oil (PO), weight of a thousand grains (WTG) and head weight (HW) of sunflower. The data showed significant difference between the treatments, when submitted to the Tukey's test. Only sunflower (PR) productivity did not present statistical difference between the treatments, indicating that irrigation with treated domestic wastewater provided similar performance to that obtained from the conventional system, where well-water irrigation plus mineral fertilization were used.

Considering the PR variable, there was no significant effect of the proportions of treated domestic wastewater and wellwater, corroborating the results of Ribeiro et al. (2011), where they irrigated castor bean with proportions/ratios of treated domestic wastewater and well-water in different experimental conditions. They verified that there was no statistical difference of PR between the treatments, 
evidencing the potential of substitution of part of the chemical fertilization, besides the economy of the water resource of quality.

In addition, T1 to T5 treatments presented PR values ranging from 961.80 to $1.321,40 \mathrm{~kg} \mathrm{ha}^{-1}$. These results were lower than those obtained by Acosta (2009), whose average grain yield reached $2,260.00 \mathrm{~kg} \mathrm{ha}^{-1}$, in the Apodi-RN Plateau, and smaller than the expected national average for the $2012 / 13$ crop of $1574 \mathrm{~kg} \mathrm{ha}^{-1}$ (Agrianual, 2014).

It was verified that the T1 treatment was the one that presented the lowest PO value in the sunflower grains. It is known that the oil content is derived from the balance between the deposition of lipids, proteins and other substances, within the genetic characteristics of the sunflower cultivar. Thus, increased nitrogen availability tends to increase protein content with decreased sunflower oil content (Steer et al., 1984).

The results of PO corroborate with Nobre et al. (2012), which produced castor bean with mineral nitrogen fertilization and noticed reduction of PO of the castor bean seeds with the increase in nitrogen doses.

Lobo and Grassi Filho (2007) used sewage sludge and mineral fertilization in sunflower production. They showed that treatments with sewage sludge increased PR and WTG values compared to treatments with mineral fertilization only, whereas for the PO variable there was no statistical difference between the treatments.

Regarding the variable WTG, Nobre et al. (2010) found results that differ from those presented in this study, where the sunflower presented increase of the WTG variable, when there was an increase in the applied treated domestic wastewater quantity.

Analyzing the orthogonal contrasts, it was observed that for the variables PO, WTG and HW, the contrast C4 (treatment T2 versus treatment T1) was significant. Treatment T1 had increase in PO value of $15.24 \%$ compared to $\mathrm{T} 2$ treatment, while $\mathrm{T} 2$ treatment provided weight gain of $18.58 \%$ and $31.80 \%$ in WTG and HW, respectively, compared to T1. The contrasts $C 1$ and $C 2$ were significant for the variables PO and WTG and PO and HW, respectively, while the $\mathrm{C} 3$ contrast was significant only for $\mathrm{PO}$ variable.

These results were discrepant in relation to those presented by Morais et al. (2012), which used orthogonal contrasts between the effluent doses of the meat industry $(25,50,75$ and $100 \mathrm{~m}^{3} \mathrm{ha}^{-1}$ ) and mineral fertilization and did not observe significant differences for the PR and WTG variables.

\section{Materials and methods}

\section{Experimental area location and characterization}

The study was conducted from September to December 2011, in the Milagres rural community at the Apodi Plateau, Rio Grande do Norte, Brazil, located between the geographical coordinates 537'38 "S and 37으' 55 "W and altitude of $150 \mathrm{~m}$ (Oliveira et al., 2014).

According to the Köppen classification, the predominant climate in the Apodi Plateau region is BSw'h ', characterized by being very hot and semi-arid, with the rainy season being late for autumn (Alvares et al., 2013). It also presents an annual average temperature of $27.1^{\circ} \mathrm{C}$, maximum average of $34.1^{\circ} \mathrm{C}$ and average minimum of $22.8^{\circ} \mathrm{C}$. The mean insolation of the region is approximately 3041 hours year ${ }^{-1}$, with average evaporation of $2190 \mathrm{~mm}$ year ${ }^{-1}$, mean relative humidity of $66.8 \%$ and mean precipitation of $893 \mathrm{~mm}$ year $^{-1}$ (Rocha et al., 2009).

The soil of the experiment area was classified as Typic Haplustept, according to the guidelines established by Embrapa (2013). Table 1 shows the physical-chemical characteristics of the soil of this experimental area in depths from 0 to $0.20 \mathrm{~m}, 0.20$ to $0.40 \mathrm{~m}$ and from 0.40 to $0.60 \mathrm{~m}$.

This Milagres rural community has 107 habitants, who live in 28 residences, generating about $20 \mathrm{~m}^{3}$ of domestic wastewater daily (Oliveira et al., 2014). All this wastewater generated in the settlement was channeled and transported to a treatment plant, consisting of a digester decant (septic tank plus two anaerobic filters), and later applied by drip irrigation units, whose sunflower crop occupied an area of $744 \mathrm{~m}^{2}$

The infrastructure and equipment used to apply proportions of treated domestic wastewater and well-water were (a) Two reservoirs $10 \mathrm{~m}^{3}$ made of reinforced concrete, with dimensions of $3.5 \mathrm{~m}$ in diameter per $1.0 \mathrm{~m}$ of depth for the storage of the treated domestic wastewater and wellwater; (b) Two pump sets with $1.5 \mathrm{hp}$ automated plus two disc filters with aperture of $130 \mathrm{~m}$ (c) Five drip irrigation units equipped with non-self-compensating emitters of $1.6 \mathrm{~L}$ $\mathrm{h}^{-1}$ of flow rate and spacing between emitters of $0.30 \mathrm{~m}$; (d) A multistage submersible pump with $9.0 \mathrm{hp}$ power for pumping water from a $150 \mathrm{~m}$ deep well.

\section{Experiment installation and conducting}

The experiment was randomized block design, with five treatments and five replicates (Figure 1). The treatments consisted of the application of treated domestic wastewater and well-water with five proportions, controlled by solenoid valves of the automation system. The treatments used were as follows: T1 $-100 \%$ of treated domestic wastewater, T2 $75 \%$ of treated domestic wastewater and $25 \%$ of well-water, T3 - 50\% of treated domestic wastewater and $50 \%$ of well water, T4 - $25 \%$ of treated domestic wastewater and $75 \%$ of well water, and $\mathrm{T} 5-100 \%$ of well water plus mineral fertilization as control.

The plant material was the sunflower (Heliantus annus) cultivar $\mathrm{H}-251$ from Embrapa, which was transplanted to the field 20 days after sowing. For this, the sowing took place in polyethylene trays of 200 cells, filled with coconut fiber substrate. The transplanting of seedlings was carried out on October 20, 2011. The spacing used in the experiment was $1.0 \mathrm{~m}$ between rows per $0.30 \mathrm{~m}$ between plants in the row. The experimental plots consisted of five rows of $2.5 \mathrm{~m}$, two edges with the central rows constituting the useful plot with 10 plants, totaling 25 plots of $12.5 \mathrm{~m}^{2}$.

The five plots submitted to the T5 treatment $(100 \%$ well water plus mineral fertilization) received base fertilization with urea, monoammonium phosphate (MAP), potassium chloride and boric acid, according to the recommendations of Ribeiro et al. (1999) for the initial development of the sunflower crop, while the other plots were only fed nutrients present in the treated domestic wastewater and well water. The water requirement of sunflower was estimated based on crop evapotranspiration (ETC). The reference value (ETo) was calculated by the FAO methodology, using the PenmanMonteith equation (Allen et al., 2006). To estimate ETc, the values of the crop coefficient $(\mathrm{Kc})$ obtained by Cavalcante 
Júnior (2011), was used at Apodi-RN. According to author, the values of $\mathrm{Kc}$ obtained for the different phases of development of the sunflower were $0.52 ; 0.70 ; 0.98$ and 0.81 for the respective phases I, II, III and IV.

During the 66-day cycle after the sunflower transplanting (DAT), an irrigation of $371 \mathrm{~mm}$ was applied, discounting the rainfall of $20 \mathrm{~mm}$ in the experimental period in all treatments. The automated solenoid valves controlled the treated domestic wastewater and well water irrigation times based on ETc; thus, defining the proportions used in this study.

\section{Physical-chemical analysis of treated domestic wastewater and well-water}

In the periods from September 22 to December 28 (2011), four samples were collected from both treated domestic waste-water and well water. The values of $\mathrm{pH}$, electrical conductivity $(\mathrm{EC})$, calcium $\left(\mathrm{Ca}^{2+}\right)$, magnesium $\left(\mathrm{Mg}^{2+}\right)$, nitrogen $(\mathrm{N})$, phosphorus $(\mathrm{P})$ and potassium $\left(\mathrm{K}^{+}\right)$were determined in the Laboratory of Analysis of Soil Water and Plant (LASWP) of the Universidade Federal Rural do SemiÁrido (UFERSA). The values of the physicochemical characteristics of treated domestic sewage and well water are presented in Table 2.

\section{Evaluated characteristics}

At 15, 45 and 60 DAT, the morphological characteristics of plant height (PH) in meters, number of leaves (NF) in unit value, stem diameter basal (SD) in centimeters and distance from one end to the other of the chapter (HD) in centimeters were evaluated. For this, ten plants were sampled, inserted in the useful area by plot, each evaluated plant was identified by tape.

The PH characteristic was determined with a metric meter graduated in centimeters, being considered as plant height the vertical distance from the soil level to the height of the insertion of the chapter, while the variable NF was determined by direct counting. With the aid of a pachymeter, the SD variable was measured at a height of approximately five centimeters from the soil surface using a metric tape to obtain HD.

The sunflower reached the harvest point on December 27, 2011at 66 DAT. The chapters of each useful plot were harvested and weighed (HW). Afterwards the grains were separated manually and weighed, yielding sunflower (PR) yield. Subsequently, samples of 1000 grains were separated for each treatment to obtain the mass (WTG).

The oil content (PO) of the grains was extracted and measured, 180 days after harvest, aiming at the minimization of the microbiological risk, when the moisture of the grains is on a dry basis of $6.4 \%$. The grains were stored in sealed plastic bags, kept in a cold room at $10^{\circ} \mathrm{C}$, until they reached equilibrium (approximately 10 days). After reaching environment temperature, the grains were crushed and placed in sachets which were subjected to extraction in a Soxhlet apparatus, using hexane as the solvent. The residual solvent was removed by rotevaporation and oven dried at $70 \circ \mathrm{C}$ in the Laboratory of environment catalysis and materials (LACAM) of the Universidade do Estado do Rio Grande do Norte (UERN).

\section{Statistical analysis}

The results of the morphological assessments (ALP, NF, DC and $D C A)$ and of production (PR, PO, PM and $P C)$ were submitted to analysis of variance by the SISVAR (Systems for Analysis of Variance) software developed by Ferreira (2011). The Tukey's test and orthogonal contrasts were performed for multiple comparison of the means.

The contrasts tested were: 1$)$ treatment - T5 versus other treatments (T1, T2, T3 and T4); 2) treatment - T4 versus treatments (T1, T2 and $T 3$ ); 3) treatment $-\mathrm{T} 3$ versus treatments ( $\mathrm{T} 1$ and $\mathrm{T} 2$ ) and 4) treatment $-\mathrm{T} 2$ versus treatment $-\mathrm{T} 1$.

The combination of the contrasts with the means of the treatments was expressed as follows:

$\mathrm{C} 1=12 \mathrm{~m} 1+12 \mathrm{~m} 2+8 \mathrm{~m} 3+10 \mathrm{~m} 4-42 \mathrm{m5}$

$\mathrm{C} 2=30 \mathrm{~m} 1+30 \mathrm{~m} 2+20 \mathrm{~m} 3-80 \mathrm{~m} 4$

$\mathrm{C} 3=6 \mathrm{~m} 1+6 \mathrm{~m} 2-12 \mathrm{m3}$

$\mathrm{C} 4=6 \mathrm{~m} 1-6 \mathrm{~m} 2$

\section{Conclusion}

The combined use of treated domestic wastewater and wellwater is a viable alternative for the substitution of mineral fertilization and reduction of water scarcity, with minimal losses in the productive potential and development of the sunflower crop. The T4 treatment (25\% treated domestic wastewater and $75 \%$ of well-water) was the most adequate for the best agronomic performance of the sunflower in the northeastern semi-arid region.

\section{Acknowledgment}

To Conselho Nacional de Desenvolvimento Científico e Tecnológico (CNPq, process 470020/2011-3) for financial support and the master's degree grant (CNPq, process 557026 / 2010-5) and the Banco do Nordeste do Brasil (BNB) for financial support.

\section{References}

Acosta, JF (2009) Consumo hídrico da cultura do girassol irrigada na região da chapada do Apodi. 57p. Dissertação (Mestrado) - Universidade Federal de Campina Grande, Campina Grande.

Allen RG, Pereira LS, Raes D, Smith M (2006) Evapotranspiración del cultivo, Guías para la determinación de los requerimientos de agua de los cultivos. Roma: FAO. 298p.

Alvares CA, Stape JL, Sentelhas PC, Gonçalves JLM, Sparovek G (2013) Köppen's climate classification map for Brazil. Meteorol Z. 22(6):711-728.

Andrade LO, Gheyi HR, Nobre RG, Dias NS, Nascimento ECS (2012) Qualidade de flores de girassóis ornamentais irrigados com águas residuária e de abastecimento. Idesia (Arica). 30(2):19-27.

Anuário da Agricultura Brasileira - Agrianual (2014) São Paulo: Agra FNP Pesquisas, 2014. 463p.

Carvalho R S, Santos Filho J S, Santana L O G, Gomes D A, Mendonça L C, Faccioli G G (2013) Influência do reuso de águas residuárias na qualidade microbiológica do girassol destinado à alimentação animal. Rev Ambient Água. 8(2):157-167. 
Cavalcante Junior EG (2011) Produção e necessidade hídrica da cultura do girassol irrigado na chapada do Apodi. 61p. Dissertação (Mestrado) - Universidade Federal Rural do Semi-Árido, Mossoró.

Empresa Brasileira de Pesquisa Agropecuária - Embrapa (2013) Sistema brasileiro de classificação de solos. Brasília: Embrapa Solos. 353p.

Fabio RS, Silva IM, Pellin DMP, Bergamin AC, Silva RP (2015) Características agronômicas do cultivo de girassol consorciado com Brachiaria ruziziensis. Rev Cienc Agron. 46(1):110-116.

Feitosa HO, Farias GC, Silva Junior RJC, Ferreira FJ, Andrade Flho FL, Lacerda CF (2013). Influência da adubação borácica e potássica no desempenho do girassol. Com Sci. 4(3):302-307.

Ferreira DF (2011) Sisvar: a computer statistical analysis system. Ciênc Agrotec. 35(6):1039-1042.

Freitas CAS, Silva ARA, Bezerra FML, Andrade RR, Mota FSB, Aquino BF (2012) Crescimento da cultura do girassol irrigado com diferentes tipos de água e adubação nitrogenada. Rev Bras Eng Agrí Ambient. 16(10):10311039.

Leoneti AB, Prado EL, Oliveira SVWB (2011) Saneamento básico no Brasil: considerações sobre investimentos e sustentabilidade para o século XXI. Rev Adm Pública. 45(2), p. 331-348.

Lima LA, Mischan MM, Neptune AML (1981) Efeitos isolado e combinado de nitrogênio, fósforo e potássio no desenvolvimento do girassol (Helianthus annuus L.). An Esc Super Agric Luiz de Queiroz. 38(2): 857-873.

Lobo TF, Grassi Filho H (2007) Níveis de lodo de esgoto na produtividade do girassol. R.C. Suelo Nutr Veg. 7(3):16-25.

Medeiros SS, Soares AA, Ferreira PA, Matos AT, Souza JAA (2005). Utilização de água residuária de origem doméstica na agricultura: estudo das alterações químicas do solo. Rev Bras Eng Agrí Ambient. 9(4):603-612.

Menezes RSC, Silva TO (2008) Mudanças na fertilidade de um Neossolo Regolítico após seis anos de adubação orgânica. Rev Bras Eng Agrí Ambient. 12(3):251-257.

Moraes MT, Silva VR, Arnuti F (2012) Resíduos líquidos de efluentes de agroindústria de carnes na produtividade do girassol. Enc Bio. 8(14):843-853.

Nobre RG, Gheyi HR, Soares FAL, Andrade LO, Nascimento ECS (2010) Produção do girassol sob diferentes lâminas com efluentes domésticos e adubação orgânica. Rev Bras Eng Agrí Ambient. 14(7):747-754.

Nobre RG, Lima GS, Gheyi HR, Medeiros EP, Soares LAA, Alves NA (2012) Oil content and yield of castor bean as affected by nitrogen fertilization and saline water irrigation. Pesq Agropec Bras. 47(7), p.991-999.

Oliveira MLA, Paz VPS, Gonçalves KS, Oliveira GXS (2017) Crescimento e produção de girassol ornamental irrigado com diferentes lâminas e diluições de água residuária. Irriga. 22(2):204-219.
Oliveira AFM, Fernandes FGBC, Batista RO, Di Souza L, Gurgel MT (2014) Teores de metais pesados em cambissolo irrigado com água residuária doméstica e água de poço. Rev Ambient Água. 9(2):302-312.

Rawashdeh HM (2017) Sunflower seed yield under trickle irrigation using treated wastewater. Afr J Agric Res. 12(21):1811-1816.

Ribeiro AC, Guimarães PTG, Alvarez VH (1999) Recomendações para uso de corretivo e fertilizantes de Minas Gerais - 5a aproximação. Viçosa: CFSEMG. 359p.

Ribeiro MCF, Felizardo AR, Santos AC, Silva JO, Peixoto MFSP, Paz VPS (2011) Crescimento e produtividade da mamoneira irrigada com diferentes diluições de esgoto doméstico tratado. Rev Bras Eng Agrí Ambient. 16(6):639646.

Rocha AB, Baccaro CAD, Silva PCM, Camacho RGV (2009) Mapeamento geomorfológico da bacia do Apodi/MossoróRN, NE do Brasil. Mercator. 8(16):201-216.

Rodrigues MB, Vilas Boas MA, Sampaio SC, Reis CF, Gomes SD (2011) Efeitos de fertirrigações com águas residuárias de laticínio e frigorífico no solo e frigorífico no solo e na produtividade da alface. Eng Ambient. 8(3):173-182.

Santos PR, Ruiz HÁ, Lima Neves JC, Freire MBGS, Freire FJ (2009) Acúmulo de cátions em dois cultivares de feijoeiro crescidos em soluções salinas. Rev Ceres. 56(5):666-678.

Santos SS, Soares AA, Matos AT, Mantovani EC, Batista RO (2006) Efeitos da aplicação localizada de esgoto sanitário tratado nas características químicas do solo. Eng Agric. 14(1):32-38

Santos Junior JÁ, Gheyi HR, Dias NS, Soares FAL, Nobre RG (2011) Doses de boro e água residuária na produção do girassol. Rev Cienc Agron. 42(4):857-864.

Soares LAA, Lima GS, Chaves LHG, Xavier DA, Fernandes PD, Gheyi HR (2015) Fitomassa e produção do girassol cultivado sob diferentes níveis de reposição hídrica e adubação potássica. Rev Bras Eng Agrí Ambient. 19(4): 336-342.

Souza JAA, Batista RO, Ramos MM, Soares AA (2010) Alteração nas características físicas do solo decorrentes da aplicação de esgoto doméstico tratado. Acta Sci Tech. 32(4):361-366.

Steer BT, Hocking PJ, Kortt AA, Roxburg CM (1984) Nitrogen nutrition of sunflower (Helianthus annus L.): Yield components, the timing of their establishment and seed characteristics in response to nitrogen supply. Field Crops Res. 9:219-236.

Weber OB, Crisostomo LA, Miranda FR, Sousa AF, Mesquita ALM, Cabral JEO. (2017). Production of ornamental sunflower irrigated with oilfield produced water in the Brazilian semiarid region. Pesq Agropec Bras. 52(6):443454. 